\title{
THE HAMSTER (MESOCRICETUS AURATUS) AS EXPERIMENTAL MODEL IN CHAGAS' DISEASE: PARASITOLOGICAL AND HISTOPATHOLOGICAL STUDIES IN ACUTE AND CHRONIC PHASES OF TRYPANOSOMA CRUZI INFECTION
}

\author{
Luis Eduardo Ramírez, Eliane Lages-Silva, José Maria Soares Júnior and \\ Edmundo Chapadeiro
}

\begin{abstract}
This research characterizes the acute and chronic phases of Chagas' disease in hamster through parasitological and histopathological studies. The acute phase was achieved with 44 young hamsters injected intraperitoneally with 100.000 blood trypomastigotes of Benedito and $Y$ strains of $T$. cruzi. The chronic phase was induced in 46 hamsters injected intraperitoneally with 35.000 trypomastigotes of Vicentina, Benedito and Y strains. Animals were sacrificed at regular intervals of 24 hours of acute phase and from the $3^{\text {rd }}$ to the $10^{\text {th }}$ month of infection of chronic phase. In the acute phase, parasites were easily recovered from all animals and there was an inflammatory reaction characterized by mononuclear and potymorphous leukocyte infiltration of variable degree in the majority of tissues and organs, specially in the connective loose and fatty tissues, smooth muscle myocardium and skeletal muscle. In the chronic phase the lesions occurred in the same tissues and organs, but the inflammatory response was less severe and characterized by mononuclear infiltration mainly with focal or zonal fibrosis in the myocardiun. In $50 \%$ of infected animals parasites were found in myocardiun and recovered from pericardic, peritoneal and ascitic fluids in some animals. Signs of heart failure, sudden death and enlargement of bowel were observed regularly. We concluded that the hamster is an useful model for Chagas'disease studies.
\end{abstract}

Key words: Chagas' disease. Experimental model. Hamster.

Many species of animals have been used as models to study the infection of $T$. cruzi, being the mouse, rat, guinea pig, rabbit, dog and the monkey the most frequently employed ${ }^{9}$. Although the susceptibility of hamster to $T$. cruzi is well known, this animal has been not used yet as an experimental model for Chagas'disease. Only a few papers describe the infection in the acute phase (AP) and no one in the chronic phase (CP).

Cariola et $a l^{10}$ infected hamsters with the Tulahuén strain of $T$. cruzi and observed nests of parasites in all organs, great inflammatory reaction, degenerative phenomena and a high hyperplasia of

Disciplina de Parasitologia, Departamento de Ciências Biológicas da Faculdade de Medicina do Triângulo Mineiro, Uberaba, MG.

Supported by FMTM-FUNEPU, FAPEMIG and CNPq.

Address to: Dr. Luis Eduardo Ramírez. Praça Manoel Terra, s/ n, 38025-050 Uberaba, MG.

Recebido para publicação em 21/03/94. the macrophagic system. They also observed high mortality rates of the infected animals. Osimani and Gurri $^{25}$ made compared between the infection of many different Uruguayan strains of $T$. cruzi and observed a higher susceptibility of mice $(100 \%)$ in relation to hamster $(65 \%)$. Schoemaker and Hoffman $^{32}$ infected mice, rats, hamsters and guinea pigs with trypomastigotes of Tulahuén strain of $T$. cruzi and observed that mice were more severely infected than the other three species and that fat tissue and the adrenal cortex were not infected.

In view of the few papers about the infection by T. cruzi in hamster and in order to search for a new experimental model for Chagas'disease, as recommended by $\mathrm{WHO}^{38}$, we decided to study this animal both in the AP and in the CP of the infection, analysing the parasitologic and the histopathologic aspects, which preliminary results were related in previous communications 2930 . 
Ramirez LE, Lages-Silva E, Soares Junior JM, Chapadeiro E. The hamster Mesocricetus auratus as experimental model in Chagas' disease: parasitological and histopathological studies in acute and chronic phases of Trypanosoma cruzi infection. Revista da Sociedade Brasileira de Medicina Tropical 27:163-169, jul-set, 1994.

\section{MATERIAL AND METHODS}

In the AP forty-four young non isogenic Syrian hamsters (Mesocricetus auratus), 34 males and 10 females, were infected intraperitoneally with 100.000 trypomastigotes from $\mathrm{Y}$ and Benedito strains of $T$. cruzi (Benedito strain was isolated through xenodiagnosis from a patient with the indeterminate form). Fifteen animals, nine males and six females, were used as controls.

The parasitologic study was performed through the direct method ${ }^{7}$ at intervals of 24 hours until the $15^{\text {th }}$ day post-infection. Three infected animals and one control were randomly sacrificed after ether anesthesia at the same intervals .

In the CP forty-six hamsters, 22 males and 24 females, in the same conditions as AP group were infected with 35.000 trypomastigotes forms from $Y$, Benedito and Vicentina strains (Vicentina strain was isolated through xenodiagnosis from a patient with chronic cardiac form) and twelve hamsters, six males and six females, were used as controls.

The parasitologic studies were performed at each 30 days through the methods of microhematocrit concentration and hemoculture (LIT mediun). At each 30 days, three to four infected animals and one control were randomly sacrificed until the $10^{\text {th }}$ month post-infection. Fragments of the same tissues and organs of the AP were obtained and also from animals that died spontaneously or from those sacrificed in general bad state.

The tissue specimens obtained at the necropsy in both experiments were fixed in $10 \%$ formalin solution and embedded in paraffin; $5-7 \mu \mathrm{m}$ sections were stained by hematoxylin-eosin (H.E) and Gomori trichromic for routine histopathologic analysis. The peroxidase - antiperoxidase immunohistochemistry test was used for tissular parasitism search.

\section{RESULTS}

During the AP all infected animals showed patent parasitemia. Those infected with the Y strain had a pre-patent period of 5 days and a maximum peak of parasitemia on $6^{\text {th }}, 9^{\text {th }}, 13^{\text {th }}$ and $15^{\text {th }}$ days with a maximum number of 4.500 trypomastigotes/ $5 \mu l$ of blood. In Benedito strain the pre-patent period was three days and the maximum peak of parasitemia was on the $8^{\text {th }}$ day with 64 trypomastigotes $/ 5 \mu 1$ of blood. The parasitemia of these animals was low and no death was observed during the AP.

In animals chronically infected (after three months) the parasitemic curves were very similar to those observed when 100.000 blood trypomastigotes were injected. Nevertheless the parasitemia was lower with the Vicentina strain, with a maximum of 16.2 trypomatigotes $/ 5 \mu l$ of blood during the AP. In this experiment, two animals infected with $\mathrm{Y}$ strain died, but no death was noticed in animals infected with the other strains. The parasitemia detected at each 30 days through microhematocrit and hemoculture methods was sometimes positive and sometimes negative.

In the AP of both experiments no important clinical signs were noticed. At necropsy infected animals showed enlargement and congestion of heart, spleen and liver. Microscopic lesions were common and progressive since the first 24 hours in the majority of tissues and organs, being more severe in the loose connective and fatty tissues (cellulitis) and the smooth muscle. The heart (Figure 1) presented carditis (peri, myo and endocarditis) early in atria and later in ventricles with mononuclear and polymorphous leucocytes infiltration of the three layers including the specific conduction tissue. The autonomic atrial ganglia, as well as the nervous twigs (ganglionitis and neuritis), were also infiltrated by the same cells with degenerative changes and nerve cells necrosis.

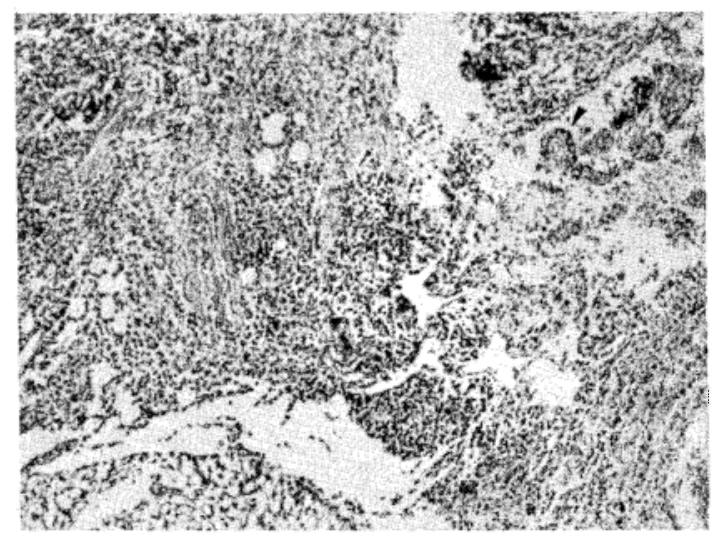

Figure 1 - Heart of infected animal sacrificed in the AP showing severe mononuclear infiltration of the loose connective and fat tissues (cellulitis) of the epicardium and ganglia (arrow). HE 4OX. 
Ramirez LE, Lages-Silva E, Soares Junior JM, Chapadeiro E. The hamster Mesocricetus auratus as experimental model in Chagas' disease: parasitological and histopathological studies in acute and chronic phases of Trypanosoma cruzi infection. Revista da Sociedade Brasileira de Medicina Tropical 27:163-169, jul-set, 1994.

In the digestive tract it was also observed acute inflamation with the same inflamatory cells mainly in the muscular layer (myositis) and myoenteric ganglia (ganglionitis) with signs of ganglion cells degeneration and necrosis (Figure 2).

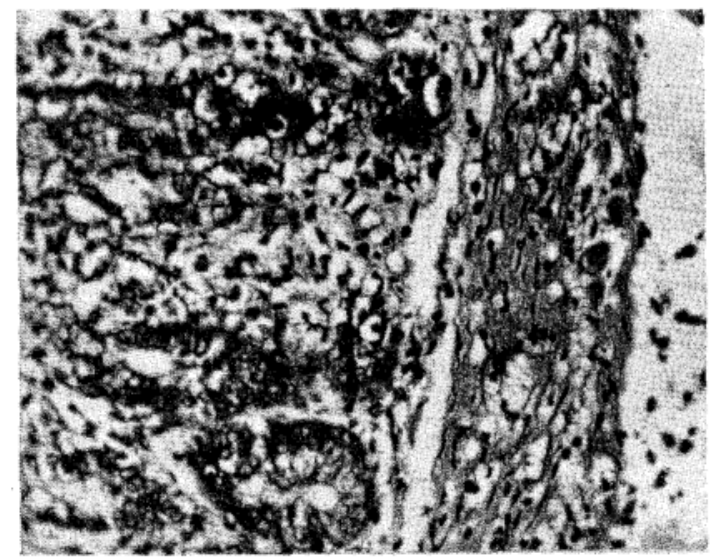

Figure 2 - Large intestine of hamster infected in the AP exhibiting severe mononuclear infiltration of the muscle layer (myositis) and myoenteric plexus (ganglionitis). HE 100X.

Genital internal lesions were early and generaly severe in the smooth muscle layer, in the interstitium of the testis (orchitis) and the adnexa (epididymitis, vesiculitis, prostatitis and funiculitis), and also in the ovary and uterus (oophoritis and metritis).

The spleen, thymus, lymph nodes and the bone marrow presented, since the beginning, a reactive state of variable intensity with phagocytosis of parasites.

Lesions in other organs as skeletal muscle (myositis), lungs and bronchia were less severe and appeared later. Adrenal glands showed nodules of mononuclear and polymorphous leucocytes in sinusoids with phagocytized parasites. Nothing was noticed in other organs of the endocrine system.

In general, the tissue parasitism in the AP was early and more severe in the loose connective and fat tissues, particularly surrounding the internal genitals, peritoneum and smooth muscle fibres of internal genitals, from the $3^{\text {rd }}$ day after-infection for both strains. In other tissues and organs the parasitism was delayed (seven to nine days after infection). No correlation between the grade of inflammatory reaction and tissue parasitism was noticed anywhere. It should be emphasized that the acute inflammatory response was present in variable degree in the absence of parasites since the first 24 hours post-infection for both strains.

In the CP, some animals presented a bad general state characterized by apathy, loss of weight, ulcerative gingivitis, pallescense, dyspnea and generalized edema; seven animals died spontaneously.

In seven animals it was observed edema in the subcutaneous fat tissue and a clear and transparent abdominal, pleural and pericardial liquid effusion. In some of these animals it was found trypomastigotes in the pleural, pericardic and ascitic fluid through microhematocrit concentration and hemoculture methods.

The heart of the majority of animals was enlarged and congested with dilatation of the cavities specially of the apex of the left ventricle with mural trombosis (Figure 3). The liver was also enlarged and congested; mild to moderate splenomegaly was noticed. In some animals, the intestinal tract, specially the bowel, presented variable degree of dilatation of the lumen (Figure 4). Atrophy of

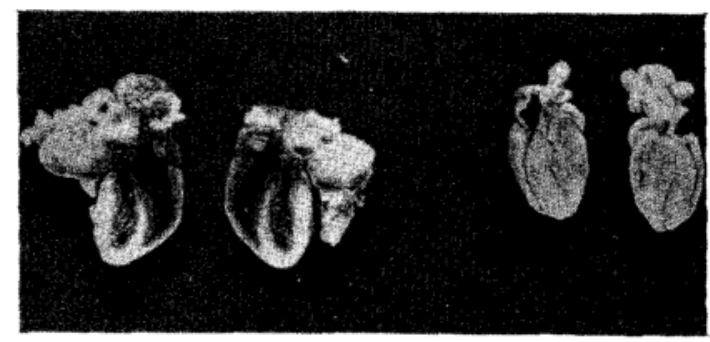

Figure 3 - Control hamster heart (right) and chronic chagasic heart (left) with dilatation of cavities (cardiomegaly).

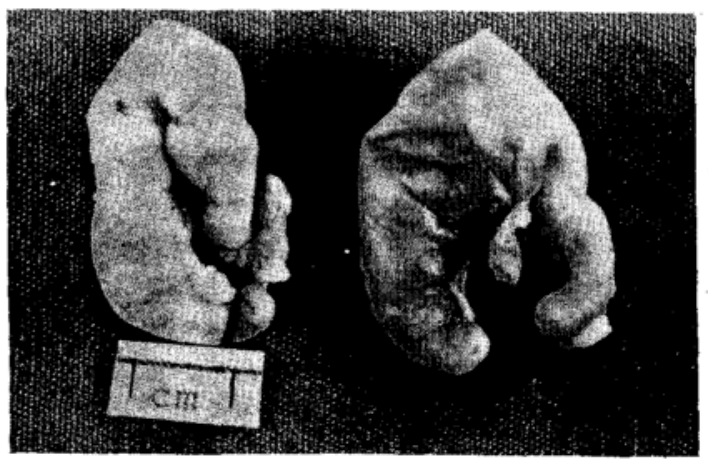

Figure 4- Control hamster bowel (left) and dilated bowel of chronic chagasic animal (right) 
Ramirez LE, Lages-Silva E, Soares Junior JM, Chapadeiro E. The hamster Mesocricetus auratus as experimental model in Chagas' disease: parasitological and histopathological studies in acute and chronic phases of Trypanosoma cruzi infection. Revista da Sociedade Brasileira de Medicina Tropical 27:163-169, jul-set, 1994.

internal genitals mainly of testis, ovary and uterus was frequent.

The microscopic lesions were relatively scanty and found in the heart, digestive tract and adnexa and internal genitals. All cardiac layers were infiltrated only by round mononuclear cells, nevertheless the myocardic lesions were more severe with focal or zonal endomisial infiltration and fibers destruction sometimes accompanied by variable extension of fibrosis (Figure 5). The myocardic specific tissue showed the same lesions. In the myocardium were found amastigote nests in $50 \%$ of infected animals. The epicardiun showed also focal or patchy areas of mononuclear infiltration as well as the autonomic cardiac ganglia and nerve twigs associated to degenerative changes and reduction of nerve cells (Unpublished data).

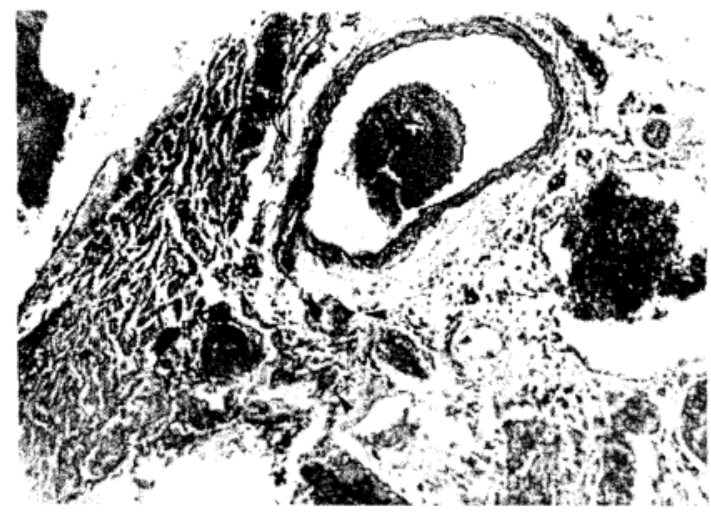

Figure 5-Hamster heart in the CP showing focal myocarditis extending to the epicardium and ganglionitis (arrow). HE 100X.

The gastro-intestinal tract presented mononuclear cells infiltration of the muscle layer (myositis) and of the nervous myoentericus ganglia (ganglionitis Figure 6). In the liver, besides the congestion, there were intralobular nodules of mononuclear infiltration, fatty degeneration of hepatocytes and deposits of Congo red stained material similar to amyloid. Chronic pancreatitis with parenchimatous atrophy was also observed.

Internal genitals exhibited chronic mononuclear cells infiltration in the testis (orchitis), epididymus (epididymitis, Figure 7), seminal vesicle (vesiculitis) and prostate (protatitis) in males and ovary (oophoritis) and uterus (metritis) in females with variable atrophy of these organs. The urinary tract

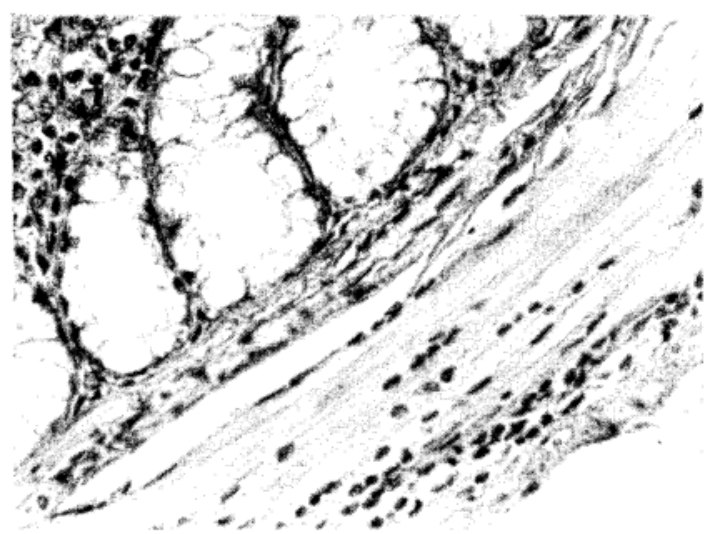

Figure 6- Large intestine from the same animal exhibiting discreet mononuclear infiltration in the muscular layer (myositis) and in the myoenteric plexus (ganglionitis) with destruction of nerve cells. $H E 400 X$.

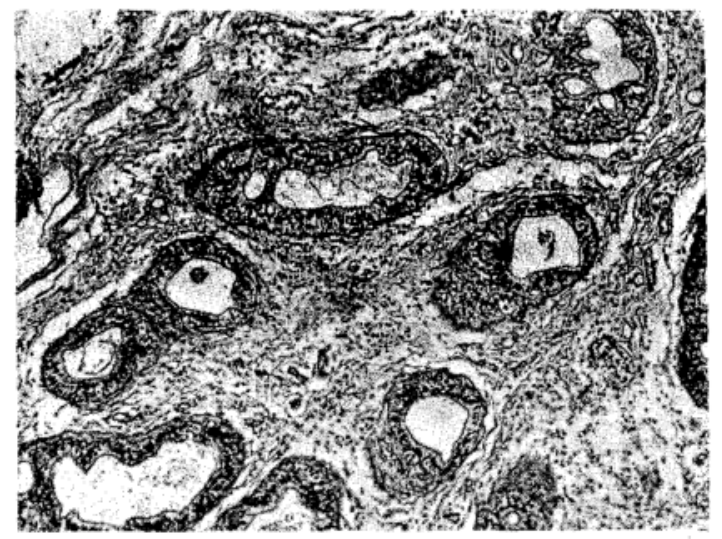

Figure 7- Epidydimus from one animal in the $C P$ showing severe mononuclear infiltration of the intersticium with tubular atrophy. $H E$ $100 x$.

showed the same chronic cell infiltration especially in the muscle layer (cystitis, ureteritis and urethritis).

The thymus, lymph nodes and spleen presented discreet chronic reactional state.

In the central nervous system there were the same chronic focal cell infiltration (encephalitis and meningitis). Focal neuritis and spinal ganglionitis with characteristic infiltrate of mononuclear cells were observed, too.

The skeletal muscles showed focal myositis with mononuclear cell infiltration and necrosis of fiber cells (Figure 8). 
Ramírez LE, Lages-Silva E, Soares Junior JM, Chapadeiro E. The hamster Mesocricetus auratus as experimental model in Chagas' disease: parasitological and histopathological studies in acute and chronic phases of Trypanosoma cruzi infection. Revista da Sociedade Brasileira de Medicina Tropical 27:163-169, jul-set, 1994.

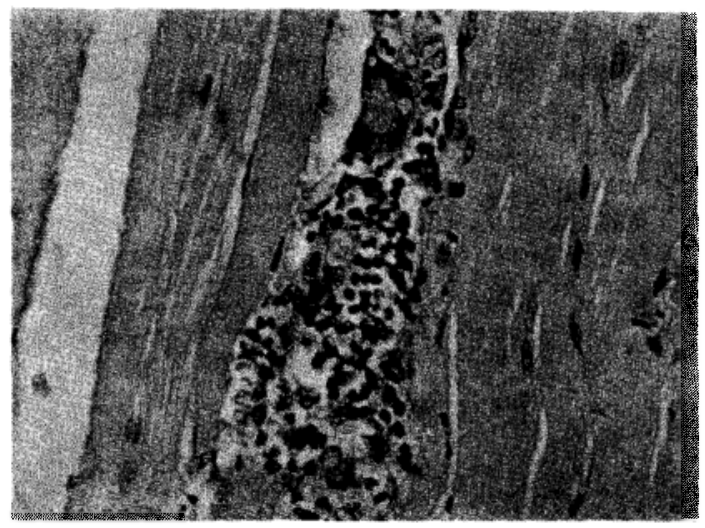

Figure 8 - Skeletalmuscle with focalchronic necrotizing myositis. HE 400x.

\section{DISCUSSION}

The parasitological behaviour of the $T$. cruzi infection in hamster (Mesocricetus auratus) during the AP showed that $Y$ strain is more virulent than Vicentina and Benedito strains. This fact is also observed when $Y$ strain is used in other experimental models ${ }^{12} 1828$. Although the inocula utilized in AP and CP were different from each other they maintained their original characteristics curves.

While the elevated number of trypomastigotes of Y strain in the AP killed the majority of mice ${ }^{4}$, infected hamsters remained in a good general state and only two deaths ocurred. This is also observed when infections are made with $\mathrm{Y}$ strain in other experimental models as rats ${ }^{12}$ rabbits $^{28}$ and dogs ${ }^{11}$ which demonstrate that the hamster has a more efficient control of the infection than mice.

The parasitemia evaluated in CP through the hemoculture and microhematocrit concentration methods, confirms that hamster does not abort the infection as does rats and other animal models ${ }^{9}$ and probably the chagasic human ${ }^{39}$. The parasite isolation from pericardic, pleural and ascitic fluids, in higher number than in blood through microhematocrit and hemoculture methods is a finding not yet related. This fact needs further studies for explanation.

Our data shows that in the AP, macroscopic and microscopic lesions in the heart and in other organs are similar to that found in $\operatorname{man}^{20}$ and in other experimental models 561219 33. It should be emphasized that the internal genitals and urinary tract of hamsters of both sexes are early and severely invaded by the same inflammatory process as described for mice ${ }^{17}$ and guinea pig $^{15}$.

The mortality in the CP occurred occasionally as consequence of the infection, heart failure or even due to immunodepression. The urinary incontinence was consequence of cystitis and probably of lesions in the hypogastric plexus (ganglionitis).

The fluid effusion in the cavities and dyspnea were probably due to the heart failure, in consequence of the chronic myocarditis. It is interesting to notice that these manifestations were not discribed in mice and rats, although it has been found in $\operatorname{dogs}^{19}$ and rabbits ${ }^{14} 2736$.

The macroscopic and microscopic findings in the majority of organs in the CP are similar to those found in other experimental models $s^{412142736}$ and humans ${ }^{20}$. The chronic carditis is more discreet, sometimes focal as in the chronic indeterminate form, sometimes zonal as in the symptomatic chronic cardiopathy. The left ventricle apex dilatation suggests the human vorticilar lesion (apical aneurism) 32331 .

The gastrointestinal tract enlargement specially of the bowel, found in some animals, may be a good model to investigate the pathogenesis of chagasic enteromegalies since this is questioned in other models $^{2122} 24$. In this phase the liver lesion were similar to those observed in acute phase but no parasites were seen in the intralobular infiltrates. The pancreas atrophy was probably due to two factors: chronic inflammation and nutritional state of animals in consequence of the infection, since controls did not show such lesions.

Skeletal muscles and the nervous system were slightly damaged as in $\operatorname{man}^{26}$ and other experimental models 1216343537 .

The urogenital organs were strongly affected in the hamster, as described in other experimental models ${ }^{13} 17$. Cystitis resulting from lesions of the muscular layer associated to the lesions of hypogastric plexus were probably the main cause of bladder enlargement and urinary incontinence. Testes, ovaries and the uterus atrophy are probably consequence of the severe chronic inflammatory process.

In summary, our studies show for the first time that the hamster reproduces the main parasitological and histopathological characteristics of human 
Ramirez LE, Lages-Silva E, Soares Junior JM, Chapadeiro E. The hamster Mesocricetus auratus as experimental model in Chagas' disease: parasitological and histopathological studies in acute and chronic phases of Trypanosoma cruzi infection. Revista da Saciedade Brasileira de Medicina Tropical 27:163-169, jul-set, 1994.

Chagas'disease infection. Although the eletrocardiografic study and radiological examination of the digestive tract are going on we can conclude that the hamster is an useful model for Chagas'disease research.

\section{RESUMO}

Opresente trabalho tem comofinalidade caracterizar as fases aguda e crônica da doença de Chagas em hamster, através de estudos parasitológicos $e$ histopatológicos. A fase aguda foi induzida em 44 hamsters jovens, inoculados intraperitonealmente, com 100.000 tripomastigotas sanguíneos das cepas $Y$ e Benedito do T. cruzi. A fase crônica foi produzida em 46 hamsters, inoculados intraperitonealmente, com 35.000 tripomastigotas sanguíneos das cepas $Y$, Vicentina $e$ Benedito. Os animais foram sacrificados a intervalos regulares de 24 horas na fase aguda, durante 15 dias $e$ na fase crônica, a partir do $3^{\circ}$ mês até o $10^{\circ} \mathrm{mês}$ da infecção. Na fase aguda, a parasita foi facilmente recuperado de todos os animais, os quais apresentaram reação inflamatória, de intensidade variável, de células mononucleares e polimorfonucleares, na maioria dos tecidos e órgãos, principalmente nos tecidos conjuntivo frouxo e adiposo, músculo liso, cardíaco e esquelético. Na fase crônica, as lesões ocorreram nosmesmos tecidos $e$ órgãos, mas a resposta inflamatória com infiltrado mononuclear foi mais grave no miocárdio onde adquiriu caráter fibrosante. No miocárdio os parasitas foram encontrados em $50 \%$ dos casos. A partir do liquido pericárdico, peritoneal e ascítico desses animais foram recuperados parasitas através do microhematócrito $e$ hemocultura. Regularmente, observaram-se sinais de insuficiência cardíaca, com morte súbita e de dilatação do intestino grosso e atrofia dos genitais internos. Conclui-se que o hamster é um modelo útil para o estudo da doença de Chagas.

Palavras-chaves: Doença de Chagas. Modelo experimental. Hamster.

\section{ACKNOWLEDGMENTS}

We thank Luzia Helena Gonçalves dos Santos and Valéria Ramos for technical assistance and Najara Vieira Galvão for help with the manuscript.

\section{REFERENCES}

1. Alcântara FG. Desnervação dos gânglios cardiacos intramurais e cervitoráxicos na molestia de Chagas. Revista Goiana de Medicina 16:259-277,1970.
2. Alencar A. Histogenese do granulona chagásico do Sistema Nervoso Central do cão. Segundo Congresso Latino-Americano de Anatomia Patologica São Paulo 51-52,1958.

3. Almeida HO. A lesão vorticilar da cardiopatia chagásica crônica. Tese de Doutorado, Universidade Federal de Minas Gerais,Belo Horizonte,MG, 1976.

4. Andrade SG. Caracterização de cepas de Trypanosoma cruzi isoladas no Recôncavo Baiano. Revista de Patologia Tropical 3:65-121,1974.

5. Andrade V, Brodskyn C, Andrade SG. Correlation between isoenzyme patterns and bio logical behaviour of different strains of Trypanosoma cruzi. Transactions of the Royal Society of Tropical Medicine and Hygiene 77: 796- 799, 1983.

6. Anselmi A, Pifano FC, Suarez JA, Dominguez A, Vasquez AD, Anselmi $G$. Experimental Schizotrypanum cruzi myocarditis. American Heart Journal 70:638-656, 1965.

7. Brener $\mathbf{Z}$. Therapeutic activity and criterion of cure on mice experimentally infected with Trypanosoma cruzi. Revista do Instituto de Medicina Tropical de São Paulo 4: 389-396, 1962.

8. Brener $Z$. Comparative studies of different strains of Trypanosoma cruzi. Annals of Tropical Medicine and Parasitology 59: 19-26, 1965.

9. Brener Z, Ramirez LE. Modelos crônicos da doença de Chagas experimental. In: Cançado JR, Chuster M (eds) Cardiopatia chagásica, Fundação Carłos Chagas, Belo Horizonte p. 29-32, 1985.

10. Cariola J, Prado R, Agosin M, Christen R. Susceptibilidad del hamster (Cricetus auratus) \& Peromyscus (Peromyscus maniculatus gambeli), a la infección experimental por Trypanosoma cruzi, cepa Tulahuén. Boletin Informativo Parasitarias Chilenas V: 44-45, 1950.

11. Castro MA, Brener Z. Estudo parasitológico e anatomo-patológico da fase aguda da doença de Chagas em cães inoculados com duas diferentes cepas de Trypanosoma cruzi. Revista da Sociedade Brasileira de Medicina Tropical 18:223-229, 1985.

12. Chapadeiro E, Beraldo PSS, Jesus PC, Oliveira Jr WP, Junqueira Jr LF. Lesões cardíacas em ratos Wistar infectados com diferentes cepas do Trypanosoma cruzi. Revista da Sociedade Brasileira de Medicina Tropical 21:95-103, 1988.

13. Ciconelli AJ. Estudo quantitativo dos neurônios do plexo hipogástrico inferior em ratos normais e em infectados experimentalmente pelo Trypanosoma cruzi. Tese de Doutorado, Universidade de São Paulo, Ribeirão Preto,SP, 1963.

14. Figueiredo F, Rossi MA, Ribeiro dos Santos R. Evolução da cardiopatia experimentalmente induzida em coelhos infectados com Trypanosoma cruzi. Revista da Sociedade Brasileira de Medicina Tropical 
Ramírez LE, Lages-Silva E, Soares Junior JM, Chapadeiro E. The hamster Mesocricetus auratus as experimental model in Chagas' disease: parasitologicaland histopathological studies in acute and chronic phases of Trypanosoma cruzi infection. Revista da Sociedade Brasileira de Medicina Tropical 27:163-169, jul-set, 1994.

18: 133-141, 1985.

15. Franco MF. Cardite experimental do cobaio pela cepa Y do Trypanosoma cruzi. Correlação entre a histopatologia e a presença de antígenos parasitários identificados por imunofluorescência indireta. Revista da Sociedade Brasileira de Medicina Tropical 23: $187-189,1990$.

16. Jardim E. Moléstia de Chagas experimental no rato: parasitismo do núcleo do III par craniano. Revista do Instituto de Medicina Tropical de São Paulo 13:405410, 1971.

17. Lamano Carvalho TL, Ribeiro RD, Lopes RA. Parasitism of the male reproductive organs by Trypanosoma cruzi (Bolivia strain). Memórias do Instituto Oswaldo Cruz 84(suppl.II):22, 1989.

18. Lana M. O cão como modelo experimental para o estudo da doença de Chagas. Tese de Doutorado, Universidade Federal de Minas Gerais, Belo Horizonte, MG, 1992.

19. Lana M, Chiari E, Tafuri WL. Experimental Chagag'disease in dogs. Memórias do Instituto Oswaldo Cruz 87:59=71,1992.

20. Lopes ER, Chapadeiro E,Tafuri WL, Prata AR. Doença de Chagas. In: Lopes ER, Chapadeiro E, Raso E, Tafuri WL (eds) Bogliolo Patologia, Rio de Janeiro, Guanabara, Koogan p. 1047-1065, 1987.

21. Marsden PD, Alvarenga NJ, Soares VA, Gama MP. Attempts to produce megasyndrome in mice using stocks of Trypanosoma cruzl associated with megaoesophagus in man. Transactions Royal Society Tropical Medicine and Hygiene, London 73: 651, 1979.

22. Marsden PD, Seah SKK, Draper CC, Pettitt LE, Miles MA, Voller A. Experimental Trypanosoma cruzi infection in rhesus monkey. II The early chronic phase. Transaction of the Royal Society of Tropical Medicine and Hygiene, London 70 : 247:251, 1976

23. Mignone $C$. Alguns aspectos da patologia da cardite chagásica crônica. Tese de doutorado, Universidade São Paulo, São Paulo-SP, 1958.

24. Okumura M. Doença de Chagas experimental, In: Raia AA (ed) Manifestações digestivas da Molestia de Chagas, São Paulo p. 35-59, 1983.

25. Osimani JJ, Gurri J. Infección experimental del hamster dorado (Mesocrycetus auratus) con algunas cepas uruguayas de Trypanosoma cruzi. Archivos de la Sociedad de Biologia de Montevideo XVIII: 73-78, 1954

26. Prata A, Porto G. Biopsia de músculo na doença de Chagas. Revista do Instituto de Medicina Tropical de São Paulo 8:193-196, 1966.

27. Ramirez LE . O coclho como modelo experimental no estudo da doença de Chagas crônica. Tese de
Doutorado, Universidade Federal de Minas Gerais, Belo Horizonte-MG, 1984

28. Ramirez LE, Brener $Z$. Evaluation of the rabbit as a model for Chagas'disease. I. Parasitological studies. Memórias do Instituto Oswaldo Cruz 82: 531- 536, 1987.

29. Ramirez LE, Lages-Silva E, Chapadeiro E. Infecção do hamster pelo Trypanosoma cruzi. Revista da Sociedade Brasileira de Medicina Tropical 24: 119$120,1991$.

30. Ramirez LE, Lages-Silva E, Soares Jr JM, Chapadeiro E. Infecção experimental do hamster pelo Trypanosoma cruzi: fase crônica. Revista da Sociedade Brasileira de Medicina Tropical 26: 253254, 1993.

31. Raso P, Chapadeiro E, Tafuri WL, Lopes ER, Rocha A. Anatomia patológica da cardiopatia crônica. In: CançadoJR, Chuster M(eds) Cardiopatia Chagásica. Fundação Carlos Chagas, Belo Horizonte p.41-53, 1985.

32. Schoemaker JP, Hoffman Jr RV. Possible stimulatory factor(s) in brown adipose tissue in mice. Experimental Parasitology 35: 272-274, 1971 .

33. Sousa MA, Alencar AA. On the tissular parasitism of Trypanosoma cruzi and strain in Swiss mice. Revista do Instituto de Medicina Tropieal de Sĩo Paulo 26: 316-321, 1984.

34. Tafuri WL, Brener Z. Lesões do sistema nervoso autónomo do camundongo albino na Tripanosomiase cruzi experimental na fase aguda. O Hospital 69: 179-191, 1966.

35. Tafuri WL, Lima Pereira FE, Bogliolo L, Raso P. Lesões do sistema nervoso autônomo e do tecido muscular estriado esquelético na fase crónica da Tripanosomose cruzi experimental. Estudos ao microscópio óptico e eletrônico. Revista Goiana de Medicina 26: 61-67, 1979.

36. Teixeira ARL, Figueiredo F, Rezende Filho J, Macedo V. Chagas'disease: a clinical, parasitological, immunological and pathological study in rabbits. The American Journal of Tropical Medicine and Hygiene 32: 258-272, 1983.

37. Vichi FL. Estudo do parasitismo na medula espinal de ratos na fase aguda da molestia de Chagas. Revista do Instituto de Medicina Tropical de São Paulo, 3: 37-42, 1961.

38. Word Health Organization. Report of the Scientific Working Group on the Development and Evaluation of Animal Models for Chagas'disease. Geneva, 1984.

39. Zeledón R, Dias JCP, Salazar-Brilla A, Rezende JM, Vargas LG, Urbina A. Does a spontaneous cure for Chagas' disease exist? Revista da Sociedade Brasileira de Medicina Tropical 21: 15-20, 1988. 